
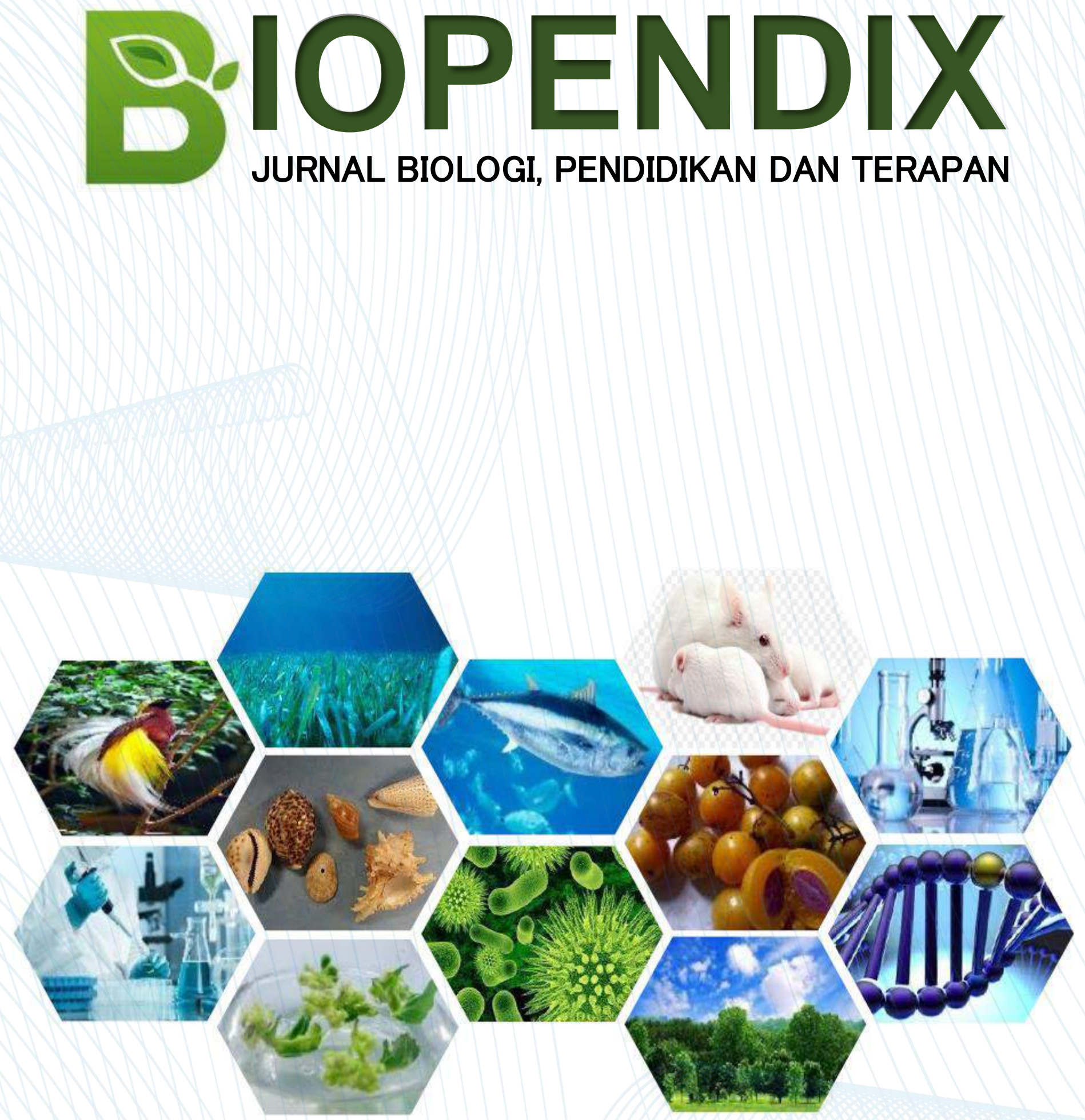

PUBLISHER BY:

BIOLOGY EDUCATION, UNPATTI AMBON - MALUKU 


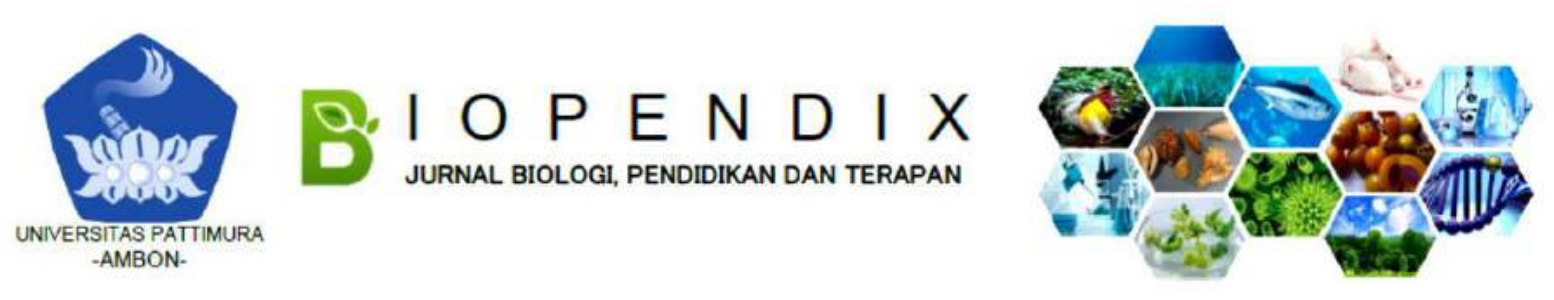

\title{
STUDI KOMUNITAS GASTROPODA DI PERAIRAN PASANG SURUT DESA HUTUMURI KECAMATAN LEITIMUR SELATAN KOTA AMBON
}

\author{
Benjamin Mornaten
}

\author{
Alumni Program Studi Pendidikan Biologi \\ *Corresponding author: Benjamin Mornaten; e-mail: bennymonaten@gmail.com
}

\begin{abstract}
Background: Ecologically, gastropods have an important role to control the population of macroalgae in coral reefs, and economically the snail shell can be used as a source of income for people, especially coastal communities.

Method: The method used is a quadratic linear transect method that is placed perpendicular to the coastline with a combination of plots on the transect line. Data analysis included species composition, diversity, dominance, and evenness of gastropod species.

Results: The results of the study were 1549 gastropod individuals consisting of 46 species of 23 genera, 17 families, 2 subclasses and 4 orders. In general, the diversity and abundance of gastropods in the coastal tidal waters of the hutumuri village are relatively moderate and the species dominance is evenly distributed.

Conclusion: Which consists of 46 species, 21 genera, 17 families and 4 orders. Ecological parameters of the gastropod community in the tidal waters of Hutumuri Village are density value $(0.97 \mathrm{ind} / \mathrm{m} 2)$, abundance value $(12.867 \mathrm{in} / \mathrm{m})$ important value $(0.2590)$, diversity value (3.0468), dominance value $(0$, $1445)$, the value of harmony (0.8010). Dominant index value (D) (0.1445) indicates no species dominance. The diversity pattern of gastropod species in the tidal waters of Hutumuri Village is having a uniform distribution pattern.
\end{abstract}

Keywords: Community, diversity, abundance, gastropods

\begin{abstract}
Abstrak
Latar Belakang: Secara ekologi gastropoda memiliki peranan penting untuk mengontrol populasi makroalga diekosistim terumbuk karang, dan secara ekonomi cangkang siput dapat dimanfaatkan sebagai sumber pendapatan bagi masyarakat terutama masyarakat pesisir.

Metode: Metode yang digunakan adalah metode transek linier kuadrat yang diletakan secara tegak lurus garis pantai dengan kombinasi plot pada garis transek tersebut. Analisa data dilakukan meliputi komposisin spesies, keanekaragaman, dominasi, dan kemerataan dari spesies gastropoda.

Hasil: Hasil penelitian di dapat 1549 individu gastropoda terdiri dari 46 spesies 23 genus, 17 famili, 2 sub klas dan 4 ordo. Secara umum keanekaragaman dan kelimpahan gastropoda di perairan pasang surut pantai desa hutumuri relatif sedang dan dominasi spesies yang merata.

Kesimpulan: Parameter ekologi komunitas gastropoda diperairan pasang surut Desa Hutumuri yaitu nilai kerapatan $\left(0,97 \mathrm{ind} / \mathrm{m}^{2}\right)$, nilai kelimpahan $(12,867 \mathrm{in} / \mathrm{m})$ nilai penting $(0,2590)$, nilai keragaman $(3,0468)$, nilai dominasi $(0,1445)$, nilai keserasian $(0,8010)$. Nilai indeks dominan (D) $(0,1445)$ menunjukan tidak ada dominasi spesies. Pola keragaman spesies gastropoda pada perairan pasang surut Desa Hutumuri adalah memiliki pola penyebaran seragam.
\end{abstract}

Kata Kunci: Komunitas, keanekaragaman, kelimpahan, gastropoda 


\section{PENDAHULUAN}

Secara geografi, Provinsi Maluku memiliki luas wilayah $7.122 .479,69 \mathrm{~km}^{2}$. Provinsi Maluku juga merupakan daerah kepulauan yang memiliki ekosistem laut yang kaya dengan berbagai sumber daya hayati, seperti ekosistem terumbu karang, ekosistem lamun, ekosistem mangrove dengan berbagai biota seperti ikan, mollusca, echinodermata dan rumput laut. Salah satu zona di daerah pantai adalah zona intertidal atau litoral atau sering disebut juga sebagai zona pasang surut (Nybakken, 1992). Zona pasang surut merupakan habitat yang sesuai untuk organismeorganisme makrobentos seperti mollusca, crutacea, dan echinodermata. Menurut Cemohorsky (1978), kurang lebih $85 \%$ jenis mollusca dijumpai pada zona pasang surut dan $98 \%$ diantaranya didominasi oleh berbagai gastropoda.

Organisme makrobentos seperti gastropoda memiliki peran penting dalam bidang ekonomi dan ekologi. Secara ekonomi gastropoda dimanfaatkan sebagai sumber pendapatan bagi masyarakat. Bagian tubuh gastropoda yang dimanfaatkan adalah daging dan cangkangnya. Daging gastropoda dimanfaatkan sebagai sumber protein hewani dan cangkangnya di gunakan sebagai bahan dasar pembuatan lantai, souvenir dan perhiasan (Dharma, 1988). Secara ekologi gastropoda merupakan salah satu komponen yang dapat menunjang kehidupan organisme serta mengontrol organisme lain dalam sistem aliran energi atau rantai makanan dalam suatu ekosistem (Hehakaya, 2005). Struktur ditunjukan oleh komposisi taksa, nilai penting, frekuensi kehadiran, keragaman jenis, spesies serta pola penyebaran spesies.

Pada penelitian ini peneliti melakukan penelitian di perairan pasang surut Desa Hutumuri Kecamatan Leitimur Selatan, Ambon. Desa Hutumuri merupakan salah satu desa di kota Ambon dengan luas wilayah $12 \mathrm{~km}^{2}$ dengan panjang garis pantai $8 \mathrm{~km}^{2}$. Bagian barat desa Hutumuri berbatasan dengan Desa Rutong, bagian timur berbatasan dengan Desa Passo, bagian utara berbatasan dengan Desa Halong, dan bagian selatan berbatasan dengan Laut Banda. Kondisi substrat pada perairan pasang surut desa Hutumuri terdiri dari karang, karang berpasir, berbatu, dan berbatu. Tipe pasang surut di desa Hutumuri adalah pasang surut semi dimulai yaitu pasang surut yang terjadi dua kali dalam sehari (Notji, 1978). Masyarakat desa Hutumuri memanfaatkan berbagai jenis gastropada untuk dikonsumsi.

Tujuan dari penelitian ini adalah untuk mengetahui struktur komunitas gastropoda pada perairan pasang surut desa Hutumuri dan untuk mengetahui kepadatan, kelimpahan, frekuensi kehadiran, nilai penting, keragaman, dormansi, keserasian dan pola penyebaran gastropoda pada perairan pasang surut.

\section{METODE}

Tipe penelitian ini adalah observasi. Penelitian ini dilakukan di perairan pasang surut Desa Hutumuri Kecamatan Leitimur Selatan Kota Ambon dan dilaksanakan pada tanggal 19 -24 Agustus 2017. Metode yang digunakan dalam penelitian ini adalah metode transek linier kuadrat. Alat dan bahan yang digunakan $\mathrm{pH}$ meter, salinometer, formalin 4\%, dan tissue rol. Analisa data menggunakan rumus kerapatan, frekuensi kehadiran, indeks keragaman jenis (Shannon dan Wiener), dan indeks dominasi.

Data untuk menghitung kerapatan adalah jumlah individu dan luas area pengambilan sampel. Rumus untuk menghitung kerapatan individu adalah sebagai berikut:

$\mathrm{Di}=\frac{\mathrm{ni}}{\mathrm{A}}$

Keterangan:

$\mathrm{Di}=$ Kerapatan individu spesies $\mathrm{ke}-\mathrm{i}\left(\mathrm{ind} / \mathrm{m}^{2}\right)$

$\mathrm{Ni}=$ Jumlah individu spesies ke-i

$A=$ Luas area pengambilan sampel

Data untuk menghitung frekuensi kehadiran adalah jumlah petak pengamatan ditemukannya individu spesies ke-i dan jumlah seluruh petak pengamatan yang dibuat, yang dinyatakan dengan rumus menurut sebagai berikut:

$F i=\frac{J i}{K} \times 100 \%$ 
Keterangan:

$\mathrm{Fi}=$ Frekuensi untuk spesies ke-i

$\mathrm{Ji}=$ Jumlah petak pengamatan terdapat ind spesies ke-i

$\mathrm{K}=$ Jumlah seluruh petak pengamatan yang dibuat

Data untuk menghitung indeks keragaman jenis adalah jumlah individu spesies ke-i dan jumlah total spesies. Indeks keragaman jenis Shannon dan Wiener dapat dihitung menurut Odum (1975) dengan rumus: $H^{\prime}=-(\Sigma$ pi In pi $)$

Keterangan:

$\mathrm{H}^{\prime}=$ Indeks keragaman jenis

pi $=$ Probalitas penting untuk setiap spesies $\mathrm{ke}-\mathrm{i}=\mathrm{ni} / \mathrm{N}$

$\mathrm{ni}=$ Jumlah individu spesies ke-i

$\mathrm{N}=$ Jumlah total spesies

Data untuk menghitung indeks dominasi adalah jumlah individu spesies ke-i dan jumlah total spesies. Dominasi spesies ditentukan berdasarkan indeks Simpson menurut Odum (1975) sebagai berikut:
$\mathbf{D}=\sum(\mathbf{p i})^{2}$

Keterangan:

$\mathrm{D}=$ Nilai indeks dominan spesies

$\mathrm{Pi}=$ Perbandingan jumlah individu spesies ke-i (ni) terhadap jumlah total spesies $(\mathrm{N})=$ ni/N

Jika $\mathrm{D}=1$ maka dominansi tinggi (ada

spesies yang dominan)

Jika $\mathrm{D}=0$ maka dominansi rendah (Tidak

ada spesies yang dominan)

\section{HASIL DAN PEMBAHASAN}

\section{Struktur Taksa Gastropoda}

Gastropoda yang ditemukan selama penelitian di desa Hutumuri sebanyak 1549 individu yang terdiri dari 46 spesies 23 genus, 17 famili, 2 sub kelas, dan 4 ordo kondisi gastropoda yang di temukan, dapat dilihat pada tabel berikut.

Tabel 1. Gastropoda di Desa Hutumuri

\begin{tabular}{|c|c|c|c|c|c|}
\hline Sub Kelas & Ordo & Famili & Genus & Spesies & $\sum$ Ind \\
\hline 1 & 2 & 3 & 4 & 5 & 6 \\
\hline \multirow{24}{*}{ Prosobranchia } & Archaco gastropoda & Trabinidae & Turbo & Turbo braneus & 25 \\
\hline & & & Lanella & Lanella cinerea & 95 \\
\hline & \multirow{8}{*}{ Archaeo gastropoda } & Trobinidae & Trochus & Trocus macolatus & 4 \\
\hline & & & & $\begin{array}{l}\text { Trocus nilaticus } \\
\text { Tectus fenestrasus }\end{array}$ & $\begin{array}{c}2 \\
93\end{array}$ \\
\hline & & Angariidae & Angaria & Angaria delphinus & 14 \\
\hline & & Neritidae & Nerita & Nerita chomoeleon & 193 \\
\hline & & & & Nerita squamolata & 190 \\
\hline & & & & Nerita costata & 103 \\
\hline & & & & Nerita albicilia & 20 \\
\hline & & Holiotidae & Holiotis & Holiatis planate & 3 \\
\hline & \multirow{14}{*}{ Mesogastropoda } & & Strombus & $\begin{array}{l}\text { Strombus labiatus } \\
\text { Strombus }\end{array}$ & 2 \\
\hline & & Strombusd & & lentiginosus & 3 \\
\hline & & ae & & Strombus mutabilis & 18 \\
\hline & & & & Lambis & 7 \\
\hline & & & Lambis & & \\
\hline & & Cymadae & Cymatium & $\begin{array}{l}\text { Cymatium } \\
\text { nicobaricum }\end{array}$ & 3 \\
\hline & & & & $\begin{array}{l}\text { Cymatium } \\
\text { muricinum }\end{array}$ & 15 \\
\hline & & Burdae & Bursa & Bursa gramularis & 9 \\
\hline & & Cypraidae & & Cypraea moneta & 111 \\
\hline & & & & Cypraea anmulus & 93 \\
\hline & & & & Cypraea feline & 1 \\
\hline & & & Cyprae & Cypraea erosa & 3 \\
\hline & & & & Cypraea vitelus & 1 \\
\hline & & & & Cypraea lynx & 2 \\
\hline
\end{tabular}




\begin{tabular}{|c|c|c|c|c|}
\hline & & & Cypraea caputser & 1 \\
\hline & Cerithidae & Cypeomorus & Clypeomonas & 31 \\
\hline \multirow{19}{*}{ Neogastropoda } & \multirow{8}{*}{ Moricidae } & Morula & Morula uva & 79 \\
\hline & & Drupa & Drupa glasularia & 4 \\
\hline & & & Drupa morum & 12 \\
\hline & & & Drupa ricidus & 41 \\
\hline & & & Drupa rubustidae & 3 \\
\hline & & Thais & Thais tuberasa & 89 \\
\hline & & & Thais oculeata & 47 \\
\hline & & Nassa & Nasa serta & 1 \\
\hline & \multirow[t]{2}{*}{ Mitradae } & Mitra & Mitra retusa & 75 \\
\hline & & & Mitrastictika & 1 \\
\hline & Costellaridae & Vexillum & Vexillum sp & 11 \\
\hline & \multirow{4}{*}{ Conidae } & \multirow{4}{*}{ Comus } & Comus frigidus & 6 \\
\hline & & & Comus ecbraeus & 40 \\
\hline & & & Comus coronatus & 16 \\
\hline & & & Comus milles & 28 \\
\hline & \multirow[t]{4}{*}{ Bucinidae } & Combarus & $\begin{array}{l}\text { Cantharus undosus } \\
\text { Contharus }\end{array}$ & 1 \\
\hline & & & fumossus & 48 \\
\hline & & & Engina mendiria & 9 \\
\hline & & Columbella & Columbella seripta & 5 \\
\hline Cephalaspidae & Bullidae & Bulla & Bulla vernicosa & 2 \\
\hline & Jumlah & & & 1549 \\
\hline
\end{tabular}

Terlihat bahwa komunitas gastropoda di perairan pasang suarut desa Hutumuri paling banyak adalah Nerita chamaeleon yaitu sebanyak 193 individu kemudian disusul oleh Nerita squamulato yaitu sebanyak 174 individu, dan spesies Cypraea moneta sebanyak 11 individu. Spesies dengan jumlah paling sedikit adalah Cypraea feline, Cypraea vitellus, Nassa serta, Mitra stictika, dan Cantharus undosus dengan jumlah 1 individu. Menurut Tan dan Clements (2008), habitat genus Nerita yaitu di batang dan akar mangrove, substrat berlumpur dan berbatu. Di pesisir pantai desa Hutumuri spsies Nerita chamaeleon ditemukan hidup berkelompok dan menepel pada substrat berbatu. Di samping itu, menurut Dharma (1988), Rupet dan Barnes (1994) anggota genus Cypraea di temukan hidup di bawah atau di balik koral atau karang yang telah mati, genus Cantharus hidup melekat di bawah batuan daerah pasang surut dan sublitoral, genus Mitra hidup disubstrat berpasir, serta anggota genus Nassa di substrat berlumpur atau dataran pasir. Kepadatan beberapa spesies gastropoda diatas ini sangat tergantung pada kondisi habitat pasang surut desa Hutumuri. Hasil penelitian yang dilakukan di desa Hutumuri ini sebagian besar adalah substrat karang berpasir, berbatu berpasir, dan berbatu. Persentase daerah yang bersubstrat karang di pesisir desa Hutumuri sebesar 20,10\% sedangkan daerah bersubstrat berpasir hanya sebesar $1,005 \%$ dan daerah yang bersubstrat berbatu sebesar $26,633 \%$. Lebih jelas dapat dilihat pada Tabel 2, di bawah ini:

\section{Tabel 2. Persentase Substrat Pada Perairan Pasang Surut Desa Hutumuri.}

\begin{tabular}{lcc}
\hline \multicolumn{1}{c}{ Substrat } & Jumlah Petak & $\mathbf{( \% )}$ \\
\hline \multicolumn{1}{c}{$\mathbf{1}$} & $\mathbf{2}$ & $\mathbf{3}$ \\
\hline Karang & 40 & 20,101 \\
Berpasir & 2 & 1,005 \\
Karang berpasir & 54 & 27,136 \\
Berbatu berpasir & 50 & 25,126 \\
Berbatu & 53 & 26,633 \\
\hline Jumlah & $\mathbf{1 9 9}$ & $\mathbf{1 0 0}$ \\
\hline
\end{tabular}

\section{Kepadatan, kelimpahan, dan Frekuensi Kehadiran Gastropoda}

Nilai kepadatan, kelimpahan, dan frekuensi kehadiran spesies gastropoda pada perairan pasang surut desa Hutumuri dapat dilihat pada tabel 3 dibawah ini. 
Tabel 3. Kepadatan, Kelimpahan, dan Frekuensi Kehadiran Spesies Gastropoda pada Perairan Pasang Surut Desa Hutumuri.

\begin{tabular}{|c|c|c|c|}
\hline Nama Spesies & Kepadatan & Kelimpahan & Frekuensi Kehadiran \\
\hline Nerita chamaelean & 0,97 & 12,867 & 0,075 \\
\hline Nerita squamolata & 0,955 & 11,875 & 0,08 \\
\hline Cypraea moneta & 0,558 & 3,364 & 0,166 \\
\hline Nerita costata & 0,518 & 5,15 & 0,101 \\
\hline Tectus fenestrasus & 0,467 & 3,207 & 0,146 \\
\hline Lanella cinerea & 0,57 & 4,136 & 0,111 \\
\hline Cypraea anmulus & 0.447 & 2,618 & 0,171 \\
\hline Thais tuberasa & 0,442 & 3,143 & 0,141 \\
\hline Mitra retusa & 0,437 & 3,107 & 0,141 \\
\hline Morula uva & 0,407 & 4,263 & 0,095 \\
\hline Thais oculeata & 0,236 & 3,357 & 0,07 \\
\hline Cypraea erosa & 0,201 & 2 & 0,101 \\
\hline Engina mendiria & 0,141 & 4 & 0,035 \\
\hline Comus milles & 0,141 & 2,545 & 0,055 \\
\hline Clypeomonas & 0,126 & 3,444 & 0,045 \\
\hline Turbo braneus & 0,126 & 1,667 & 0,075 \\
\hline Nerita albicilia & 0,101 & 6,667 & 0,015 \\
\hline Cymatium nicobarium & 0,009 & 2,571 & 0,035 \\
\hline Strombus mutabilis & 0,009 & 1,636 & 0,055 \\
\hline Conus coronatus & 0,008 & 1,333 & 0,06 \\
\hline Anggaria delphinus & 0,007 & 1,273 & 0,055 \\
\hline Drupa morum & 0,006 & 4 & 0,015 \\
\hline Vexullum sp & 0,055 & 3,667 & 0,015 \\
\hline Bursa granularis & 0,045 & 1,286 & 0,035 \\
\hline Lambis-lambis & 0,035 & 1,4 & 0,025 \\
\hline Conus frigidus & 0,003 & 1,5 & 0,02 \\
\hline Columbella seripta & 0,025 & 1 & 0,02 \\
\hline Cyprae vitellus & 0,02 & 4 & 0.0005 \\
\hline Drupa grosularia & 0,02 & 4 & 0,0005 \\
\hline Cymatium muricinum & 0,02 & 1,333 & 0,015 \\
\hline Trochus moculatus & 0,02 & 1 & 0,02 \\
\hline Drupa rusbussidae & 0,015 & 3 & 0,0005 \\
\hline Strombus lentiginesus & 0,015 & 1,5 & 0,01 \\
\hline Cyprae erosa & 0.015 & 1 & 0,015 \\
\hline Bulla verniosa & 0,01 & 2 & 0,055 \\
\hline Haliotis planate & 0,01 & 2 & 0,0005 \\
\hline Cyprae lynx & 0,01 & 1 & 0,01 \\
\hline Strombus labiatus & 0,01 & 1 & 0,01 \\
\hline Trochus niloticus & 0,01 & 1 & 0,01 \\
\hline Cantharus undosus & 0,005 & 1 & 0,0005 \\
\hline Cyprae capuster & 0,005 & 1 & 0,0005 \\
\hline Cyprae feline & 0,005 & 1 & 0,0005 \\
\hline Drupa ricinus & 0,005 & 1 & 0,0005 \\
\hline Mitra stictica & 0,005 & 1 & 0,0005 \\
\hline Nassa serta & 0,005 & 1 & 0,0005 \\
\hline Jumlah & 7,751 & 128,633 & 2,248 \\
\hline
\end{tabular}

Canthorus undosus, Cypraea caputser, Cypraea felinna, Drapa ricidus, Mitra stictika, dan Nassa serta yakni 0,005 ind/m dapat di lihat pada table 3. Kelimpahan

tinggi dipengaruhi oleh total petak pengamatan dimana spesies tersebut ditemukan. Spesies dengan kelimpahan tertinggi adalah Nerita chamaeleon yaitu 
sebesar $12,867 \mathrm{ind} / \mathrm{m}^{2}$, sedangkan spesies dengan kelimpahan terendah adalah Canthorus undosus, Bulla vernicosa, Cypraea capuster dengan nilai kelimpahan untuk setiap spesies adalah $1 \mathrm{ind} / \mathrm{m}^{2}$. Frekuensi kehadiran yang tertinggi dipengaruhi oleh jumlah petak pengamatan dimana suatu spesies ditemukan dari keseluruhan total petak pengamatan yang digunakan. Frekuensi kehadiran tertinggi adalah Cypraea anulus yaitu, sebesar 0,171, sedangkan frekuensi kehadiran terendah adalah Cantharus undosus, Bula vernicosa, Drapa ricidus adalah 0,005 ind $/ \mathrm{m}$, karena kehadiran spesies ini dalam jumlah individu yang paling sedikit dalam luasan $1 \mathrm{~m}^{2}$.

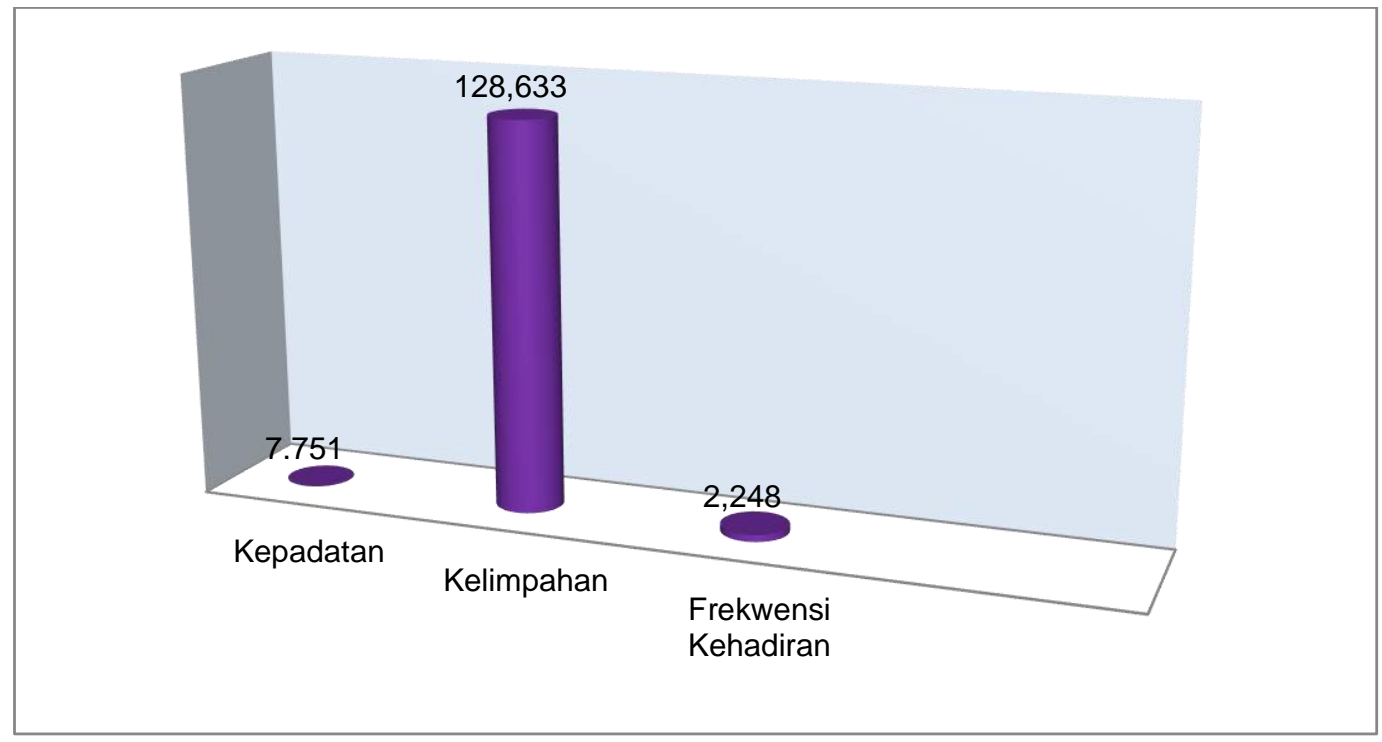
Gambar 1. Grafik Kepadatan, Kelimpahan dan Frekuensi Kehadiran Gastropoda Pada
Perairan Pasang Surut Desa Hutumuri

Bentuk grafik kepadatan dan Frekuensi kehadiran memiliki bentuk yang hampir sama karena, nilai kepadatan yang tertinggi dipengaruhi oleh jumlah individu suatu spesies yang banyak dan tersebar pada semua petak pengamatan. Sedangkan bentuk grafik kelimpahan dipengaruhi oleh total individu suatu spesies dan total petak pengamatan dimana spesies di temukan.

\section{Nilai Penting}

Data nilai penting atau indeks nilai penting (INP) setiap spesies gastropoda di perairan pasang surut desa Hutumuri dapat dilihat pada tabel 4 di bawah ini:

Tabel 4. Nilai Penting Spesies Gastropoda yang di Temukan di Perairan Pasang Surut Desa Hutumuri.

\begin{tabular}{|c|c|c|c|c|c|}
\hline No & Nama Spesies & INP & No & Nama Spesies & INP \\
\hline 1 & 2 & 3 & 4 & 5 & 6 \\
\hline 1 & Nerita chamaelean & 0,259 & 24 & Drupa grosularia & 0,036 \\
\hline 2 & Nerita squamolata & 0,252 & 25 & Cyprae vitellus & 0,036 \\
\hline 3 & Cypraea Moneta & 0,173 & 26 & Bursa granularis & 0,032 \\
\hline 4 & Cyprae anmulus & 0,155 & 27 & Lambis-lambis & 0,028 \\
\hline 5 & Nerita costata & 0,152 & 28 & Conus frigidus & 0,027 \\
\hline 6 & Tectus fenestrasus & 0,151 & 29 & Columbella seripta & 0,025 \\
\hline 7 & Thais tuberasa & 0,145 & 30 & Cyprae vitellus & 0,022 \\
\hline 8 & Mitra retusa & 0,144 & 31 & Conus coronatus & 0,021 \\
\hline 9 & Lanella cinerea & 0,141 & 32 & Cymatium muricinum & 0,020 \\
\hline 10 & Morula uva & 0,129 & 33 & Trochus moculatus & 0,019 \\
\hline
\end{tabular}




\begin{tabular}{llllll}
\hline 11 & Conthorus fumosus & 0,093 & 34 & Haliotis planate & 0,019 \\
12 & Thais oculeata & 0,088 & 35 & Bulla verniosa & 0,019 \\
13 & Conus coronatus & 0,087 & 36 & Strombus labiatus & 0,018 \\
14 & Nerita albicilia & 0,072 & 37 & Cyprae erosa & 0,017 \\
15 & Clypeomorus subbreviculus & 0,067 & 38 & Strombus labiatus & 0,014 \\
16 & Engina mendiria & 0,065 & 39 & Trochus niloticus & 0,014 \\
17 & Comus milles & 0,063 & 40 & Cyprae lynx & 0,014 \\
18 & Turbo braneus & 0,063 & 41 & Cantharus undosus & 0,011 \\
19 & Strombus mutabilis & 0,049 & 42 & Nassa serta & 0,011 \\
20 & Cymatium nicobarium & 0,048 & 43 & Cyprae feline & 0,011 \\
21 & Drupa morum & 0,046 & 44 & Cyprae capuster & 0,011 \\
22 & Anggaria delphinus & 0,044 & 45 & Mitra stictica & 0,011 \\
23 & Vexullum sp & 0,042 & 46 & Drupa ricinus & 0,011 \\
\hline
\end{tabular}

Data Tabel 4, menunjukan bahwa ada 46 spesies gastropoda yang mempunyai nilai penting kurang dari 1 . Namun 46 spesies yang di peroleh tersebut diketahui bahwa Nerita chamaeleon adalah spesies gastropoda memiliki nilai tertinggi sebesar 0,259 dan di ikuti oleh Nerita sqamulato sebesar 0,252 . Sementara nilai penting yang terendah yakni sebesar 0,011 di temukan pada beberapa spesies gastropoda antara lain Cantharus undosus, Cypraea caputser, Cypraea felinna, Drapa ricidus, Mitra stictika, dan Nassa.

Indeks nilai penting di tentukan oleh kepadatan relatif, kelimpahan relatif dan frekuensi relatif masing-masing spesies. Menurut Soegianto (1994), tingkat kepentingan suatu spesies dinyatakan dengan nilai penting yang menggambarkan dominasi spesies tertentu dalam komunitas. Tingginya nilai penting dari Nerita chameleon menunjukan bahwa spesies ini merupakan spesies yang dominan dengan yang cukup banyak dalam komunitas walaupun pada table 3 menunjukan bahwa Neritha chameleon memiliki kepadatan dan kelimpahan tertinggi namun dengan frekuensi kehadiran tertinggi adalah Cyprae annulus. Rendahnya nilai penting dari Cantharus undulus, Cyprae capulser, Cyprae lynx, Drupa rabusidae, Drupa ricidus, Mitra stictika, dan Nassa serta menunjukan bahwa spesies ini tidak dominan dan mempunyai jumlah yang sedikit dalam komunitas gastropoda di perairan pasang surut desa Hutumuri. Spesies dengan nilai penting tertinggi menunjukan bahwa spesies tersebut memiliki jumlah yang cukup banyak didalam komunitas dan merupakan spesies yang dominan. Sebaliknya spesies dengan nilai penting yang rendah merupakan spesies yang hadir dalam jumlah yang relatif sedikit dalam komunitas (Budiman \& Damedi, 1988).

\section{Keragaman, Dorminasi dan Keserasian}

Data hasil pengamatan yang diperoleh berupah nilai keragaman dominasi dan keserasian spesies gastropoda di perairan desa Hutumuri dapat disajaikan pada Tabel 5 berikut ini:

\section{Tabel 5. Nilai Keragaman, Dominasi dan Keserasian Gastropoda di Perairan Pasang Surut Desa Hutumuri.}

\begin{tabular}{lc}
\hline \multicolumn{1}{c}{ Indeks ekologi } & Rata-rata \\
\hline Keragaman $(H)$ & 3,0468 \\
Dominasi $(D)$ & 0,1445 \\
Keserasian $(e)$ & 0,8010 \\
\hline
\end{tabular}

Data Tabel 5 dapat diketahui nilai keragaman gastropoda pada perairan pasang surut Desa Hutumuri yaitu, sebesar 3,0468 . Tinggi nilai keragaman di pantai Desa Hutumuri karena jumlah spesies yang ditemukan sebanyak 46 spesies dengan jumlah individu sebanyak 1549 individu gastropoda. Menurut Krebs (1994), keragaman suatu spesies ditentukan oleh dua komponen yang berbeda yaitu jumlah spesies dan jumlah individu. Jika jumlah spesies yang diamati sama, maka nilai keragaman akan ditentukan oleh jumlah individu dari setiap sepsis yang terdapat pada masing-masing komunitas.

Berdasarkan standar keragaman yang ditentukan oleh Shanon-Wienner hasil keragaman spesies gastropoda di perairan pasang surut Desa Hutumuri memiliki nilai 
lebih dari 3. Nilai ini mengindikasikan bahwa keragaman spesies gastropoda memiliki tingkat keragaman yang tingi. Menurut Odum (1975), jika indeks keragaman <1 maka keragaman spesies rendah, sedangkan bila nilai $>3$ maka keragaman tinggi.

Tinggi nilai keragaman spesies gastropoda disebabkan tipe substrat yang beragam yaitu berbatu, berpasir, berpasir berkarang, campuran karang berpasir dan berbatu berpasir Tabel 2. Menurut Burnes dan Rupert, 1988) bahwa spesies gastropoda merupakan kelas dari mollusca yang paling sukses dalam siklus hidupnya. Karena adanya variasi habitat dimana spesies gastropoda mampu hidup pada berbagai substrat di dasar perairan. Beberapa faktor lingkungan yang diduga menyebabkan tingginya nilai keragaman gstropoda adalah: Faktor suhu, Salinitas dan $\mathrm{pH}$ serta faktor asosiasi antar spesies. Odum (1988), menyatakan bahwa keragaman spesies cenderung akan tinggi jika faktorfaktor lingkungan berada dalam kisaran toleransi bagi kehidupan suatu spesies.

\section{Pola Penyebaran}

Pola penyebaran dalam suatu komunitas menunjukan interaksi spesies tersebut dengan lingkungan tempat hidupnya Odum (1975), menyatakan bahwa individu-individu dalam suatu populasi tersebar dalam tiga pola dasar yaitu acak, seragam dan berkelompok. Pola penyebaran acak umumnya terjadi pada lingkungan yang sangat seragam dan tidak ada kecendrungan suatu spesies untuk mengumpul. Pola penyebaran seragam terjadi jika kompetisi atau persaingan antara individu spesies sangat kuat yang menyebabkan adanya pembagian ruang yang sama sedangkan pola penyebaran kelompok atau pola penyebaran yang paling umum ditemukan dalam suatu komunitas. Menurut Krebs (1988) mengatakan bahwa faktor yang mempengaruhi pola dari suatu spesies antara lain adanya interaksi antara spesies yang satu dengan yang lain seperti predator, parasite, kompetisi, penyakit dan ketersediaan makanan pada substrat. Dengan demikian dapat dikatakan bahwa pola penyebaran (distribusi) dari suatu spesies sangat penting dalam menentukan karakteristik dari suatu komunitas.
Dari hasil perhitungan terlihat bahwa pola penyebaran spesies gastropoda pada perairan pasang surut di Desa Hatumuri adalah pola penyebaran seragam (Tabel 6). Hal ini di sebabkan karena adanya kompetisi atau persaingan antara individu spesies gastropoda sangat kuat yang menyebabkan adanya pembagian ruang yang sama.

\section{Tabel 6. Pola Penyebaran Gastropoda di Perairan Pasang Surut Desa Hutumuri.}

\begin{tabular}{lcc}
\hline \multicolumn{1}{c}{ Substrat } & Jumlah Petak & (\%) \\
\hline \multicolumn{1}{c}{$\mathbf{1}$} & $\mathbf{2}$ & $\mathbf{3}$ \\
\hline Karang & 40 & 20,101 \\
Berpasir & 2 & 1,005 \\
Karang berpasir & 54 & 27,136 \\
Berbatu berpasir & 50 & 25,126 \\
Berbatu & 53 & 26,633 \\
Jumlah & 199 & 100 \\
\hline
\end{tabular}

\section{Parameter Fisik Kimia}

Hasil pengukuran faktor fisik kimia air laut di perairan pasang surut Desa Hutumuri dapat dilihat pada Tabel 7 di bawah ini.

\section{Tabel 7. Parameter Fisik Kimia Air Laut di Perairan Pasang Surut Desa Hutumuri.}

\begin{tabular}{lcc}
\hline \multicolumn{1}{c}{ Substrat } & Jumlah Petak & (\%) \\
\hline \multicolumn{1}{c}{$\mathbf{1}$} & $\mathbf{2}$ & $\mathbf{3}$ \\
\hline Karang & 40 & 20,101 \\
Berpasir & 2 & 1,005 \\
Karang berpasir & 54 & 27,136 \\
Berbatu berpasir & 50 & 25,126 \\
Berbatu & 53 & 26,633 \\
Jumlah & 199 & 100 \\
\hline
\end{tabular}

Hasil pengukuran suhu di perairan pasang surut menunjukan bahwa suhu di perairan pasang surut adalah $29,3^{\circ} \mathrm{C}$. Suhu yang cocok untuk kehidupan organisme air laut yaitu antara $27-37^{\circ} \mathrm{C}$. Ini berarti suhu diperairan pasang surut masih berada dalam toleransi untuk kehidupan gastropoda. Umumnya spesies gastropoda hidup diperairan dengan salinitas 31-37\%. Salinitas air diperairan pasang surut masih berada dalam toleransi untuk kehidupan gastropoda. Disamping itu nilai $\mathrm{pH}$ air laut di di perairan pasang surut adalah 7,8. 


\section{SIMPULAN}

1. Terdapat 1549 Spesies gastropoda di perairan pasang surut Desa Hutumuri. Yang terdiri dari 46 spesies, 21 genus, 17 famili dan 4 ordo.

2. Parameter ekologi komunitas gastropoda diperairan pasang surut Desa Hutumuri yaitu nilai kerapatan $\left(0,97 \mathrm{ind} / \mathrm{m}^{2}\right)$, nilai kelimpahan $(12,867$ $\mathrm{in} / \mathrm{m})$ nilai penting $(0,2590)$, nilai keragaman $(3,0468)$, nilai dominasi $(0,1445)$, nilai keserasian $(0,8010)$.

3. Jenis gastropoda yang mempunyai nilai kepadatan dan kelimpahan tertinggi adalah Nerita squamulato dengan nilai kepadatan sebesar $0,97 \mathrm{ind} / \mathrm{m}$ dan kelimpahan $\left(12,867 \mathrm{ind} / \mathrm{m}^{2}\right)$. Sedangkan spesies dengan nilai kepadatan dan kelimpahan terendah adalah Canthorus undosus dan Bulla vernicosa.

4. Nilai frekuensi kehadiran tertinggi spesies gastropoda adalah Cyparae annubus dengan nilai sebesar $(0,171)$. Sedangkan spesies dengan nilai terendah adalah Canthorus undosus dan Bulla verniosa.

5. Nilai indeks dominan (D) $(0,1445)$ menunjukan tidak ada dominasi spesies.

6. Pola keragaman spesies gastropoda pada perairan pasang surut Desa Hutumuri adalah memiliki pola penyebaran seragam.

7. Parameter kimia perairan (suhu, $\mathrm{pH}$, dan salinitas), pada perairan pasang surut Desa Hutumuri masih berada dalam kisaran toleransi bagi kehidupan spesies gastropoda.

\section{DAFTAR PUSTAKA}

Barnes, R.I. \& E.E. Ruper, 1988, Invertebrata Zoologi, 6. Eds. Sauders College Publishing, Philadelpia, 105

Budiman, A. \& Darmedi, 1982. Struktur Komunitas moluska di hutan mangrove
Morowali, Sulawesi Tengah. Porsiding seminar nasional II Ekosistim Mangrove.

Dharma, B. 1988. Siput dan keong Indonesia (Indonesia Shells I). PT Sarana Graha Jakarta

Dharma, B. 1988. Siput dan keong Indonesia (Indonesia Shells II). PT Sarana Graha Jakarta

Hehakaya, Y. H, 2005. Potensi Sumber Daya Gastropoda pada perairan desa Rutong kecamatan Baguala Fakultas Perikanan Universitas Pattimura Ambon

Krebs, C. L. 1978. Ekologi the Expereimen Analysis of Departemen and Abudance Second Editation and Row, New York.

Krebs, C. L. 1978. Ekologi the Expereimen Analysis of Departemen and Abudance Second Editation Haeper Collins collage publisher. The University of Brifish California.

Notji, A. 1978, Laut Nusantara, Penerbit Djambatan, Jakarta.

Nybakken, J. W. 1992. Biologi Laut Suatu Pendekatan Ekologi, terjemahan dari Marine Biologi and Ekologi oleh Eideman, M. Koesoehiono, PT. Gramedia, Jakarta.

Odum, E.P. 1971. Foundamental of Ecological W.B. Sounders Company, Philadelphia.

Odum, E. P. 1975. Foundamental of Ecological W.B. Sounders Company, Philadelphia.

Odum, E. P. 1988. Dasar-Dasar Ekologi Edisi ke-3 Gajah Mada University Press Jogjakarta.

Soegianto, A. 1994. Ekologi Kuantatif Metode Analisa Populasi dan Komunitas, Usaha Nasional Surabaya.

Tan, K. S. \& Reuben, Clements. 2008. Taksonomi dan Distribusi dari Neritidae Moluska Gastropoda di Singapura. 